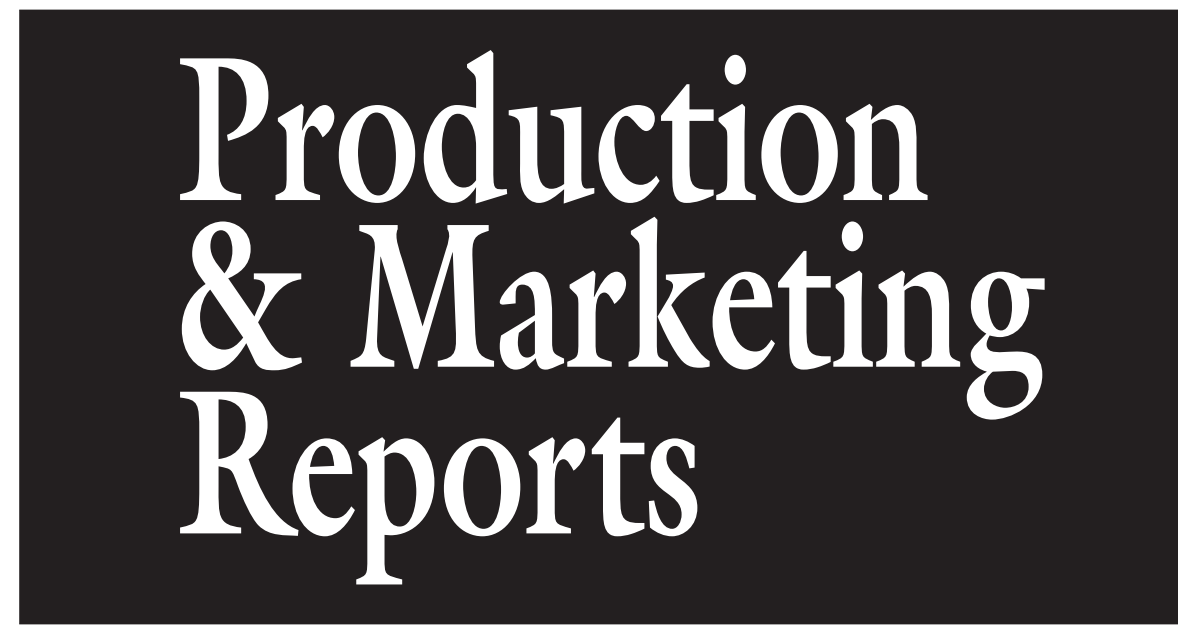

\title{
The Organic Farming Movement in Turkey
}

\author{
Cengiz Sayin ${ }^{1}$, Robin G. Brumfield ${ }^{2}$, M. Nisa Mencet $^{3}$, and \\ Burhan Ozkan ${ }^{4}$
}

ADDITIONAL INDEX WORDS. organic farming, organic agriculture, regulations, market structure, food, Turkey

SumMaRY. In the past decade, organic production has become a growing segment of the healthy food market. Organic farming is expanding gradually in many countries, and consumption of organic products is gaining a huge importance in the developed countries, such as the U.S., countries in the European Union (EU), Canada, and Japan. The increase of domestic market demand in developed countries and export potential for developing countries has stimulated organic agricultural production. In this report, we briefly examine the development of the world organic market and examine regulations with regard to production and certification. We also provide a detailed review of the current structure of organic food production and marketing in Turkey, a developing country with advantages to increase organic production. The overall picture of organic products in Turkey seems very positive. The size of the domestic market for organic products is estimated to be $\$ 3$ to $\$ 5$ million, with annual growth projected to be about $50 \%$ for the next 5 years. Eighty percent of current production in Turkey is exportoriented. The EU has been the main export destination. The positive market outlook will no doubt create a renewed interest in organic products among Turkish farmers and policy makers.

W orld population has been increasing continuously $(1.4 \%$ per year) in the past decade (U.S. Department of Commerce, 2003). This increase, coupled with the

\footnotetext{
${ }^{1}$ Assistant Professor and Specialist in Agricultural Policy, University of Akdeniz, Faculty of Agriculture, Department of Agricultural Economics, 07070, Antalya, Turkey; e-mail: csayin@ akdeniz.edu.tr

${ }^{2}$ Professor and Specialist in Farm Management, Rutgers University, 55 Dudley Road, New Brunswick, NJ 08901-8520; e-mail: Brumfield@Aesop.Rutgers.Edu

${ }^{3}$ Research Assistant in Agricultural Policy, University of Akdeniz, Faculty of Agriculture, Department of Agricultural Economics, 07070, Antalya, Turkey; e-mail: nmencet@akdeniz.edu.tr

${ }^{4}$ Professor and Specialist in Farm Management, University of Akdeniz, Faculty of Agriculture, Department of Agricultural Economics, 07070, Antalya, Turkey; e-mail: bozkan@akdeniz.edu.tr
}

limitations of arable land in the world, led to an accelerated thrust to provide methods to increase productivity per unit area. These efforts have escalated and adequate food availability has become an important issue. Developing countries have concentrated on the use of chemical inputs, such as fertilizers and pesticides, to increase agricultural productivity. The industrialization of agriculture and the development of synthetic chemicals and fertilizers allowed farmers to increase yields and reduce risks. These increased yields resulted in lower per-unit costs (Brumfield, 1996). Today, less than 2\% of the U.S. population now works in production agriculture, compared to $17 \%$ in 1940 . Average U.S. farm size increased from 168 acres in 1990 to 441 acres in 2002 (U.S. Department of Agriculture, 2002). Worldwide, agricultural productivity increased dramatically because of increased mechanization, new technologies, increased chemical and fertilizer use, and specialization.

Although increased yields are a benefit to both producers and consumers, several disadvantages have resulted from the use of agricultural chemicals. As farmers increased the rate and frequency of chemical applications, some target insects have developed resistance to particular chemicals, and some pest populations have increased dramatically (U.S. National Research Council, 1986; U.S. Office of Technology Assessment, 1995). Some have blamed industrial agriculture for other unintended costs, such as topsoil depletion, groundwater contamination (U.S. General Accounting Office, 1991), damage to wildlife, decline in the number of family farms, erosion of rural community economies, applicator health risks, and concerns about chemical residues in foods (Feenstra et al., 1996; Hanson et al., 1990; Lichtenberg, 1992).

This negative image of industrial agriculture has led to the development of several alternative approaches to reduce petrochemical inputs. These include low input agriculture, integrated pest management, integrated crop management, biodynamic agriculture, agro-ecology, regenerative agriculture, and organic agriculture (Brumfield, 2000). Among those new approaches, organic farming is one of the most widespread in the U.S. and in Europe (Rigby et al., 2001). Words such as "biologic," "ecologic," and "biodynamic" are used in place of "organic" in various countries (Export Promotion Center of Turkey, 2003). Undoubtedly, the meaning behind these expressions is more important

\begin{tabular}{llll}
\hline $\begin{array}{l}\text { Units } \\
\begin{array}{l}\text { To convert U.S. to SI, } \\
\text { multiply by }\end{array}\end{array}$ & U.S. unit & SI unit & $\begin{array}{l}\text { To convert SI to U.S., } \\
\text { multiply by }\end{array}$ \\
\hline 0.4047 & acre(s) & ha & 2.4711 \\
0.9072 & ton $(s)$ & t & 1.1023
\end{tabular}


than the actual words used. Nevertheless, most of the definitions of "organic agriculture" include an economically sustainable production and natural processes of ecosystems, such as soil organism activities, nutrient cycling, and species distribution and competition, are incorporated directly and indirectly as crop management tools aimed at protecting the soil, plants, animals, and environment (Greene, 2001; Kevan et al., 1997; Sayin, 2002). Even if organic production methods are less harmful to humans, the environment, animals, and plants than conventional agriculture, they must be economically viable if they are to succeed (Brumfield, 2000).

Organic farming systems rely on ecologically based practices such as cultural and biological pest management. The Final Rule of the U.S. National Organic Program, issued 2 May 2002, defines organic production as a system that integrates "cultural, biological, and mechanical practices that foster cycling of resources, promote ecological balance, and conserve biodiversity." The U.S. requirements prohibit the use in organic production of synthetic chemicals, sewage sludge as fertilizer, hormones to promote animal growth, antibiotics given to animals, and biotechnology. Processed foods may not be irradiated. Anyone producing or handling both organically produced food and non-organic products must never commingle them at all stages of production and must guard against the organic food coming in contact with any substances that are not allowed in organic production (Food Institute, 2004).

The main objective of this report is to explore the current structure of organic agricultural production and marketing in Turkey, a large developing country strategically located in both Europe and Asia. We focus on Turkey due to its large organic-production potential because of its traditionally low use of chemically intensive agricultural inputs and its focus on export-oriented organic production. In the first part of this report, we define institutional systems and production possibilities, and provide a background on historical developments. We focus on the development of the organic food sector in the world and regulations with regard to production and certification in the first part of this report. Finally, we present advantages and challenges of organic agricultural production in Turkey.

\section{Developments of global organic agriculture}

The global organic food market is one of the fastest growing areas of the global food market with sales exceeding \$21.5 billion in 2000. The share of the EU world retail food and beverage market was $44.3 \%$, followed by the U.S. (37.1\%), Japan (11.6\%), Canada $(3.8 \%)$, and other countries (3.2\%) (Export Promotion Center of Turkey, 2003). Although total organic food sales is only around $1 \%$ of the total food market, it is growing about $20 \%$ to $30 \%$ per year in many developed countries such as the United Kingdom (U.K.), Australia, Japan, the U.S., Italy, and Spain. For example, organic food sales in the U.K. are expanding rapidly with a $30 \%$ annual sales increase, but growth rates in the U.K. are still lower than those of some other European countries (Aikaterini, 2001). The increase of domestic market demand in developed countries such as the U.S., Canada, Austria, Japan, and the EU countries has resulted in an increase of imported organic products into these countries. The developing countries, in recognizing the growth potential of their export business, have helped to meet this rising demand by increasing production, therefore stimulating a sustained growth in organic agriculture.

Organic market capacity and organic food demand have been rapidly expanding recently. Organic foods are produced commercially in more than 130 countries around the world. About $70 \%$ of these are developing countries located in Asia and Africa. Developed countries have become main target markets for organic exporters. For example, Germany is the biggest importer of organic products in the world and the majority of its import is from developing countries (Achilles, 1999).

A great variety of organic products is traded in the worldwide market, including vegetables, animal products, various processed foods, and beverages. In recent years, trade capacity of processed food has expanded dramatically. Certification procedures of organic products are generally applied by European agencies since the EU states are the major importers of organic products (Kortbech-Olesen, 2000).

Additionally, it is noteworthy that several countries experiencing transitional economies, in particular the Czech Republic, Hungary, Poland, and the Baltic States, place high importance on organic agriculture. In 2001, the EU market for organic products was estimated at just below $\$ 9$ billion and grew to $\$ 10-11$ billion in 2003 (Kortbech-Olesen, 2003).

\section{Developments of organic production and marketing structure in the EU}

Production structure IN THE EU. Eighty percent of the current organic production in Turkey is produced for export. Thus, Turkey must comply with EU regulations. Let us look at the organic production and marketing structure in Turkey. We present the total area of organic production and the number of organic farmers in the EU in Table 1. In 2000, over 139,000 farms, utilizing about 4 million ha $(3 \%$ of the total arable land in the EU) produced organic products (Foster and Lampkin, 2000). Organic farms represent $2 \%$ of the total number of farms in the EU. Based on the total land in organic production and the number of organic farms, Italy has one-quarter of the total organic area and one-third of the total number of organic farms in the EU. Austria, Spain, Sweden, U.K., and Germany follow Italy in terms of organic production. In 1998, the total agricultural area was 128 million ha in the EU, whereas the share of organic area in the total agricultural area was $2.9 \%$. This ratio increased to $3.1 \%$ in 2000 and $3.5 \%$ in 2003 . An average organic farm size was 28.3 ha in 2000 in the EU (Directorate-General for Agriculture, 2004; Foster and Lampkin, 2000; Research Institute of Organic Agriculture, 2004).

According to results of a survey

Table 1. Total organic farm lands and number of organic farms in the European Union (1985-2000). ${ }^{\mathrm{z}}$

\begin{tabular}{ccc}
\hline Year & $\begin{array}{c}\text { Total organic } \\
\text { farm land (ha) }\end{array}$ & $\begin{array}{c}\text { Total organic } \\
\text { farms (no.) }\end{array}$ \\
\hline 1985 & 94,430 & 6,318 \\
1990 & 290,905 & 14,824 \\
1995 & $1,407,850$ & 59,752 \\
1996 & $1,756,670$ & 74,489 \\
1997 & $2,301,943$ & 94,113 \\
1998 & $2,822,776$ & 116,285 \\
1999 & $3,489,128$ & 132,179 \\
2000 & $3,944,953$ & 138,919 \\
\hline
\end{tabular}

${ }^{2}$ Foster and Lampkin, 2000

$\mathrm{y} 1 \mathrm{ha}=2.47$ acres. 
Table 2. The number of organic farms and land area under organic management in the European Union (Feb. 2004). ${ }^{z}$

\begin{tabular}{lrrrrr}
\hline & \multicolumn{2}{c}{ Organic land area } & & \multicolumn{2}{c}{ Organic farms } \\
\cline { 2 - 3 } & \multicolumn{1}{c}{$(\mathbf{h a})^{\mathbf{y}}$} & $\mathbf{( \% )}$ & & $\mathbf{( n o . )}$ & $\mathbf{( \% )}$ \\
\hline Italy & $1,168,212$ & 24.4 & & 49,489 & 35.5 \\
U.K. & 724,523 & 15.1 & & 4,057 & 2.9 \\
Germany & 696,978 & 14.5 & & 15,628 & 11.2 \\
Spain & 665,055 & 13.9 & & 17,751 & 12.7 \\
France & 509,000 & 10.6 & & 11,177 & 8.0 \\
Austria & 297,000 & 6.2 & & 18,576 & 13.3 \\
Sweden & 187,000 & 3.9 & 3,530 & 2.5 \\
Denmark & 178,360 & 3.7 & 3,714 & 2.7 \\
Finland & 156,692 & 3.3 & 5,071 & 3.6 \\
Portugal & 85,912 & 1.8 & & 1,059 & 0.8 \\
Others & 591,613 & 15.3 & 31,930 & 16.3 \\
\hline EU Total & $4,792,381$ & 100.0 & 139,330 & 100.0
\end{tabular}

${ }^{2}$ Willer and Richter, 2004.

${ }^{y} 1 \mathrm{ha}=2.47$ acres.

carried out by Stiftung Oekologie and Landbau (SOEL), in 2004 the total organic farming area in the EU has reached 4.9 million ha. Italy maintains the largest area with 1.2 million ha. The U.K., Germany, and Spain each have approximately the same area of organic production, about 0.8 million ha (Table 2) (Willer and Richter, 2004).

MARKeting STRUCTURE AND PURSUED POLICIES IN THE EU. As of 2000 , the EU represented $44.3 \%$ of the world retail food and beverage market (Export Promotion Center of Turkey, 2003). Farmers market organic food in many ways (i.e., through retail and specialized stores and through direct sales). However, retail stores market the largest proportion of organic sales. The choice of marketing channel differs depending on the country. For example, specialized stores are the most common venue for selling organic products in The Netherlands, and therefore they would be a more desirable marketing channel than retail stores for producers selling in The Netherlands (Sayin, 2002).

Organic products imported into the EU originate from about 60 countries. Developing countries have a great opportunity to benefit from the organic market in the EU (Barrett et al., 2002). The EU generally prefers cereals, fruit, vegetables, potatoes, dairy products, oil, seeds, eggs, and wine in terms of organic imports. The biggest importing countries in the EU are Germany, Denmark, and Luxembourg. The U.S., Australia, Canada, Hungary, and Israel are the main exporters of organic food to the EU. Fruit, however, is supplied to the EU from Turkey.
All countries importing into the EU must comply with EC Regulation No. 2092/91, which regulates the standardization and certification of organic products (Council of the European Union, 1991). Article 11 of EC Regulation No. 2092/91 regulates the import of organic agricultural products into the EU from thirdworld countries. Non-EU countries who do not meet all standards outlined in Article 11 cannot export organic produce to the EU (Barett et al., 2002). For this reason, Turkey has legislated new regulations in accordance with EU Article 11 to be able to export organic produce directly to the EU. The proper certification of organic produce is the main requirement for organic trade either within the EU or between the EU and third-world countries. In 2003, 364 organic certification bodies existed in the world, $79.7 \%$ of which were in the EU, the U.S., Japan, Canada, and Brazil (Rundgren, 2003).

EC Regulation No. 2092/91 is the only comprehensive regulation that has a direct effect on organic agriculture; however, some other extensive policies have indirect effects. These are the Common Agriculture Policy $(\mathrm{CAP})$, reorganized in the framework of Agenda 2000, the environmental policies of the EU, and national programs directed at organic farming policies pursued by the EU member states (Sayin, 2002).

Guidelines on subjects such as environmental protection and improving food safety and quality are now included as part of CAP reform's new aims. Thus, CAP gives agricultural production suitable to environment, plant, and animal health more attention than did previous policies. The new reforms gather legal arrangements providing direct support to producers under one umbrella (horizontal rules) and give high priority to supporting environmentally friendly production. EU member states accept these arrangements, which also limit or cease unfriendly production methods harm- ful to the environment, as a common rule (Sayin, 2002).

The EU included rural development in the scope of these reform arrangements. They embodied all legal arrangements related to this issue are under EC Regulation No. $1257 / 1999$. This regulation encourages environmentally friendly production techniques by increasing support related to the use of these techniques. Therefore, Articles 22 through 24 of the regulation address only agricultural environment and in this regard place a high priority on supporting organic agricultural production activities (Council of the European Union, 1999).

The EU's pursuit of environmental policies via CAP has not only reformed the policies, but also indirectly aimed to make the transition to organic farming attractive. Presently, the "Sixth Environment Action Program," known as "Environment 2010: Our Future and Our Choice," is in practice. In the scope of this program, the subjects and adopted principles are parallel with the aims of organic agricultural production (Commission of the European Communities, 2002).

In addition to these, each member state in the EU has national programs to stimulate organic agricultural production. However, the national programs are not comprehensive. Subsidies for different crops and regions support organic producers in the EU. But, some countries support producers of only certified organic farms (Foster and Lampkin, 2000).

Subsidies within the national organic agriculture program of EU member states support not only the production of organic products, but also farmers' marketing activities. However, only producers who affiliate with marketing organizations may benefit from these subsidies. The subsidies help develop the organic marketing concept and encourage food processing (Foster and Lampkin, 2000).

The role of the public related to organic production is to provide input for EC Regulation No. 2092/91, give subsidies to organic farmers (per hectare), purchase the organic products, and solve the general problems encountered. Advisory services supported by various producer organizations are widely used by the public and private sectors (Haccius and Lunzer, 2000). 


\section{Development of organic agriculture in turkey}

Production structure of ORgANIC PRODUCTs. Turkey is an agriculture-based country. Agricultural activities in Turkey are an indispensable element of rural life. The majority of consumable products is met by domestic production; and the majority of farms are small, highly fragmented family farms. Farmers in Turkey, and many other developing countries, use few or no chemical inputs, such as fertilizers and pesticides, compared to developed countries. In other words, chemical usage in developing countries is less than in developed countries, and thus gives an important advantage to farmers in developing countries in the process of transition to organic agriculture.

Turkey has a rich ecological structure and suitable natural background for organic agriculture. Turkey's geographical shape is a peninsula, with many microclimatic regions. Traditional methods of agricultural production in Turkey have evolved over many years and have become diverse, thereby contributing to the development of opportunities for organic production. The EU is the primary export market for Turkish organic products. Turkey has an economic advantage of low labor costs compared to other competitors.

Turkey's commercial organic agricultural production dates back to the beginning of the 1980s. After 1985, Turkey rapidly started to produce "certified organic products" for export. The first organic farmers used "contract farming." At first, the Aegean region was the center of organic production, but production later expanded throughout the country (Sayin, 2002). In the past, a few farms in very small areas produced organic crops, but today, organic production takes place on 12,435 organic farms using 44,553 ha of arable land, yielding 160,239 t of total organic crops (Table 3) (Schayes, 2001).

Dried fruit constitutes the highest component of Turkish organic agriculture, in terms of both production and export. About 59.2\% of organic farms in Turkey produce dried fruit and nuts. Furthermore, $51.1 \%$ of Turkey's total production area and $62.2 \%$ of the total organic production volume is dried and crustaceous fruit. The dried fruit

Table 3. The number of organic farms, production area, and quantity by produce group in Turkey (1999). ${ }^{\mathrm{z}}$

\begin{tabular}{|c|c|c|c|c|c|c|}
\hline \multirow[b]{2}{*}{ Products } & \multicolumn{2}{|c|}{ Organic farms } & \multicolumn{2}{|c|}{ Area } & \multicolumn{2}{|c|}{ Total production } \\
\hline & (no.) & $(\%)$ & $(\text { ha })^{y}$ & $(\%)$ & $(t)^{x}$ & $(\%)$ \\
\hline Dried fruit and nuts & 7,364 & 59.2 & 22,772 & 51.1 & 99,733 & 62.2 \\
\hline Fresh fruit & 1,786 & 14.4 & 2,557 & 5.7 & 10,600 & 6.6 \\
\hline Vegetables & 77 & 0.6 & 363 & 0.8 & 2,730 & 1.7 \\
\hline Field crops & 1,238 & 10.0 & 10,718 & 24.1 & 33,331 & 20.8 \\
\hline $\begin{array}{l}\text { Aromatic and } \\
\text { medicinal plants }\end{array}$ & 421 & 3.4 & 4,137 & 9.3 & 3,029 & 1.9 \\
\hline Others & 1,549 & 12.5 & 4,005 & 9.0 & 10,636 & 6.6 \\
\hline Total & 12,435 & 100.0 & 44,553 & 100.0 & 160,239 & 100.0 \\
\hline
\end{tabular}

${ }^{\mathrm{z}}$ Schayes, 2001 .

${ }^{\mathrm{y}} 1 \mathrm{ha}=2.47$ acres.

group is followed by field crops, fresh fruit, aromatic and medicinal plants, and vegetables, respectively (Table 3 ) (Schayes, 2001).

Turkey's export potential for organic products has resulted in an increased range of available goods. Currently, Turkish farmers produce approximately 91 kinds of organic products. In spite of this expansion in number of producers, the processed organic agricultural market is mostly limited to frozen fruit, vegetables, and fruit juice concentrates. Technical requirements for making many other product varieties available to the worldwide market limit the diversity of additional processed production.

LEGAL AND INSTITUTIONAL STRUCTURE OF ORGANIC PRODUCTION. Turkey passed its first national regulation on production, processing, and marketing of organic items on 18 Dec. 1994. The regulation was based upon EU Regulation No. 2092/91. The regulation gave the Turkish Ministry of Agricultural and Rural Affairs (MARA) the authority to oversee the original regulation. MARA established two committees to provide guidance and support to the organic sector. The National Steering Committee of Organic Agriculture is responsible for policy formulation, and the Committee of Organic Agriculture is responsible for implementation (Schayes, 2001).

Control, certification, processing, and exporting companies have direct relations with producers. Companies contract between exporters and producers, or they can contract directly with producers. Control and certification companies inspect production for MARA, determine whether production complies with the legislation, and give certification in the name of the Organic Agriculture Legislation. Processing and/or exporting companies provide production by contracting with farmers and processing or exporting available products (Sayin and Mencet, 2003).

Some organizations have responsibilities that define the rules, control, and provide technical advice. These organizations consist of the Ecologic Agriculture Organization (EAO), MARA, Aegean Exporter Union (AEU), and some advisory companies. MARA recommends legal regulations for organic agricultural production via the Ecologic Agricultural Commission and conducts studies for the adaptation to regulatory changes in the EU. Furthermore, MARA controls organic agricultural practices in terms of harmonizing the EU legislations. EAO, founded in 1992, is a member of the International Federation of Organic Agriculture Movements (IFOAM). The main task of EAO is to conduct activities such as holding symposiums and panels in relation to organic agriculture. The Aegean Exporter Union is responsible for orienting exports. Its responsibilities include registering and coordinating organic exports. Advisory companies also provide services to producers, export firms, and people who are interested in organic agricultural practices (Sayin and Mencet, 2003).

CONSUMPTION STRUCTURE OF ORGANIC PRODUCTS. Domestic marketing of organic products is a relatively new activity in Turkey. The few studies that were conducted on marketing organic products found that Turkish consumers are just becoming aware of the organic product concept. Various studies in other countries uncovered many factors that affect consumers' willingness to purchase organic products. The most significant determinants were education, income, and gender. Results from these studies are incon- 
sistent about consumer willingness to pay for organic products. A recent research study showed that consumers of organic products are characterized as affluent, well educated, and concerned about health and product quality (Lohr, 2001). However, some studies indicated that food safety concerns decrease as income increases (Buzby et al., 1995; Byrne et al., 1991; Dunlap and Beus, 1992; Jussaume and Judson, 1992). Most studies have shown that consumers' willingness to pay a premium to purchase organic food increases with income (A. Elnagheeb and J. Jordon, unpublished; van Ravenswaay and Hoehn, 1991). Some basic results from the marketing research-related studies for Turkey are summarized as follows (Akgungor et al., 1999; Ozkan et al., 2000; Sayin et al., 2003; Schayes, 2001):

- The main reason that consumers purchase organic products is that they consider organic products to be safer than conventional products.

- Consumers believe that the quality of conventionally produced fresh fruit and vegetables is decreasing, and they have serious concerns regarding food safety.

- The majority of consumers believe that pesticide residue exists on fresh fruit and vegetables.

- Most consumers do not have much information about organic products.

- Health problems related to food encourage consumers to buy organic products.

- "Price sensitivity" is the main factor affecting consuming organic products for the majority of consumers.

- Demand for organic food is very sensitive to consumer income level. Generally, as consumer income increases, demand for organic food also increases. The same applies to education.

- Organic products are about $30 \%$ to $40 \%$ more expensive than conventional products.

- Organic products are generally sold by big supermarkets, but in recent years specialized markets have also sold organic products.

- Two types of consumers demand organic products. Some consumers demand organic products mainly due to health concerns, while others demand organic products because of their awareness of the overall benefit of organic food consumption.

- The value of organic food in the domestic Turkish market is about $\$ 3-5$ million in a $\$ 23$ billion Turkish food market. These figures indicate that the organic food market in Turkey, as in other countries, is a small share of the general food market.

- Turkey's geographic proximity to EU countries and Turkey's relatively low production costs give Turkey a competitive advantage in producing and marketing organic products.

- The main Turkish organic products are dried grapes, dried figs, dried apricots, and hazelnuts.

- A small number of growers produce organic fresh fruit and vegetables for the domestic market.

- Turkish farmers have faced serious limitations in techniques to process and store organic fresh fruit and vegetables. Therefore, growers generally tend to dry fruit and vegetables. Solving these technical problems could result in an increased diversity of organic products for both domestic and export markets.

- Fifty retailers sell organic products in Turkey. In addition, big supermarkets also sell certified organic products, and are generally located in the big cities, such as Istanbul, Ankara, and Izmir.

Because of its history of exporting dried grapes, dried figs, dried apricots, and hazelnuts to the EU, Turkey will most likely continue to be the primary supplier of these products. If technical problems for processing other products can be resolved, new products can also be supplied to EU countries. The demand for organic products in the EU will probably continue to grow, and Turkey will continue to be a key player. As domestic consumers are given more information about organic products, and as the population becomes more affluent and educated, the domestic market for organic products will also expand.

MARKETING CHANNELS OF ORGANIC PRODUCTS. The majority of Turkish organic products are exported, and the EU has been the main export destination. The current marketing structure is mainly organized as export firms. Although domestic market capacity is not large, it is developing based on producer and consumer consciousness about organic production. Two marketing channels exist in the organic products market, namely direct and indirect sales. However, in recent years, sales through the specialized shops marketing channel have made this a prominent sales channel. Within the context of direct sales, farmers deliver their product directly to consumers at the local markets, farm markets, and at the farm (Sayin, 2002).

In the indirect market, organic products reach the consumer by various channels. Farmers sell their produce to supermarkets, agribusiness firms, or export companies. The main indirect marketing channel for organic products is through export companies. These companies sell the organic products mainly to foreign markets (Sayin, 2002).

Direct sales are based on trust, since organic products are sold domestically without certification. In contrast, the indirect market sells certified products. Growers selling to export firms have a contract agreement with the export firm. The majority of export firms operating in Turkey are foreign firms who operate with the local farmers in the framework of partnerships or similar agreements (Sayin, 2002).

EXPORT STRUCTURE OF ORGANIC PRODUCTs. Organic products have been produced in Turkey since the mid 1980s. In the early years, organic production was started to meet foreign market demand and production was based on the "contract agreement." As of the year 2000, 69 organic products were exported with a total quantity of 17 million $t$ and a value of $\$ 27$ million. Hazelnuts, dried grapes, dried figs, and dried apricots account for $65 \%$ to $70 \%$ of the total export value of Turkey's organic products (Table 4) (Export Promotion Center of Turkey, 2003).

Developed countries are the main importers of organic products. On the other hand, they are also very important exporters of organic products. The EU, the U.S., Canada, and Japan are important export markets for organic products. The EU is the leading export destination market for Turkish organic products. Germany is the largest market in the European market followed by France, the U.K., and The Netherlands. The EU is followed by the U.S., Japan, Austria, Canada, Switzerland, and Israel as export destination markets for Turkish organic goods (Schayes, 2001).

Dried fruit is the main Turkish organic export. In fact, dried fruits have 
Table 4. The quantity $(\mathrm{t})$ and export value $(\$ 1000)$ of organic products in Turkey (1999-2002). ${ }^{\mathrm{z}}$

\begin{tabular}{|c|c|c|c|c|c|c|c|c|c|c|c|c|}
\hline \multirow[b]{2}{*}{ Products } & \multicolumn{3}{|c|}{1999} & \multicolumn{3}{|c|}{2000} & \multicolumn{3}{|c|}{2001} & \multicolumn{3}{|c|}{2002} \\
\hline & $(t)^{y}$ & $\begin{array}{c}\text { Value } \\
(\$ 1000)\end{array}$ & $(\%)$ & $(t)^{y}$ & $\begin{array}{c}\text { Value } \\
(\$ 1000)\end{array}$ & $(\%)$ & $(t)^{y}$ & $\begin{array}{c}\text { Value } \\
(\$ 1000)\end{array}$ & $(\%)$ & $(t)^{y}$ & $\begin{array}{c}\text { Value } \\
(\$ 1000)\end{array}$ & $(\%)$ \\
\hline Dried apricot & 1,045 & 3,033 & 12.9 & 1,050 & 2,344 & 11.2 & 1,050 & 2,805 & 10.2 & 1,710 & 3,608 & 13.2 \\
\hline Dried fig & 1,580 & 3,556 & 15.1 & 1,733 & 3,308 & 15.9 & 2,207 & 4,765 & 17.3 & 1,326 & 4,248 & 15.5 \\
\hline Hazelnut & 879 & 4,036 & 17.1 & 1,039 & 4,009 & 19.2 & 1,878 & 5,076 & 18.4 & 2,982 & 4,722 & 17.2 \\
\hline Others & 4,886 & 8,787 & 37.3 & 4,197 & 6,566 & 31.6 & 7,177 & 10,064 & 36.5 & 5,665 & 9,900 & 36.1 \\
\hline
\end{tabular}

${ }^{2}$ Export Promotion Center of Turkey, 2001.

${ }^{y} 1 \mathrm{t}=1.1$ ton

been traditional export products of Turkey for many years, making Turkey the most important dried fruit-producing country in the world. However, organic vegetables produced in the Turkish greenhouses are not common since greenhouse growers use synthetic pesticides and fertilizers.

PRICE POLICIES PURSUED FOR ORGANIC FOOD MARKETING. Food labeling is a very important issue in organic food marketing and is governed by the EU regulations. Generally, wholesalers and processors prefer to buy organic products in huge quantities via boxes and sacks $(50-80 \mathrm{~kg})$, while final consumers prefer small package sizes (Tozan and Ertem, 1998).

Organic products are primarily preferred by consumers for food safety reasons. In addition, some organic foods are demanded for medicinal purposes. These demands and preferences have driven organic food prices higher than prices for conventionally grown food. Price premiums for organic products vary, depending on the type of product. In a study comparing tomatoes produced using conventional,
IPM, and organic systems, the price premium in the U.S. for organic tomatoes was found to be $30 \%$ (Brumfield et al., 2000). The price premium for organic products is about $30 \%$ to $40 \%$ in Turkey (Schayes, 2001). The price premium is generated by demand for the product as well as cost of production factors, and expenses to meet the market requirements outlined in the regulations. The prices vary widely over time because of seasonal trends in production and consumption patterns in various markets (i.e., supply and demand).

Expansion of the domestic organic market depends not only on foreign demand but also on domestic demand. Price premiums are more likely to positively affect domestic production than production for export.

Turkey has indirectly supported conventional agricultural production via price and input subsidies and decoupled payments. However, Turkey has no certain price policy for organic agriculture. Organic producers do not need government assistance because of the export-oriented production.
Thus, the organic sector in Turkey has developed its own dynamics.

Export companies give different support payments to producers in accordance with contracts, thus giving this sector a dynamic market structure. But it is necessary for Turkey to develop public policy to self-regulate and take precautions in both the domestic and competitor markets.

ADVANTAGES AND CHALLENGES OF ORGANIC PRODUCTION FOR TURKEY. Turkey has many advantages in organic agricultural production, and some challenges to overcome (Sayin, 2002; Schayes, 2001). Turkey has maintained the fastest growth of any Organisation for Economic Co-operation and Development (OECD) country in the past 10 years. Turkey has traditionally used few chemical inputs in agricultural production. Turkey has a young population eager to adopt trends and the domestic organic market has shown potential for growth. Turkey produces very few highly processed organic products. However, if techniques can be developed for producing these products, the growth potential is

Table 5. Advantages and challenges of organic agriculture in Turkey.

Advantages

Turkey has seen the fastest sustained economic growth among $\mathrm{OECD}^{\mathrm{z}}$ countries for the past 10 years (1993-2003); also, it has a dynamic structure.

Organic products which have just entered the domestic market are experiencing solid expansion.

Chemical input usage is low in organic agricultural production. The domestic organic beverage market has great marketing opportunities.

Turkey has a young population that is eager to adopt new trends in food and lifestyles.

Currently, few highly processed/frozen organic products, and no chocolates, candies, gums, etc., are produced in Turkey.

Therefore, great new market opportunities in these products are available.

\section{Challenges}

Organic producers are beginning to focus on the domestic market, but control and certificate companies are lacking.

Differences in standards and certification systems and new regulations in export markets could be a trade barrier for Turkish organic products.

Economic crises have emerged several times and have negatively influenced the demand for organic products.

Widespread awareness of what a certified organic product means is lacking. Producers and consumers need more information.

The great majority of Turkish consumers are price and income sensitive. 
tremendous. Turkey needs to establish agencies to certify organic production with standards that are consistent with EU regulations. Educational programs need to be developed to inform Turkish farmers and consumers about certified organic products. We summarize these advantages and challenges of organic agriculture in Turkey in Table 5 .

\section{Conclusion and suggestions}

Organic farming is one of the fastest-growing trends in the food industry. As consumer demand for organic foods rises in the world, more farmers will switch to organic production. Consumers have a high propensity to purchase organic foods. The research results from previous studies indicated that organic food demand depends on high disposable household income, age, and educational level. Among these factors, the education and income level are the most important factors affecting consumer purchasing behaviors of organic products. Developed countries constitute a target market for organic exporters from developing countries. Generally, developing countries neglect their domestic markets because of the smaller domestic market potential compared to the export potential. Thus, Turkey has focused primarly on its export market, but it also has a growing domestic market. On the other hand, organic products are specialized products with special requirements related to consumer characteristics, market structure, and range of organic products. Turkish exporters will need to follow consumer trends in the export market to hold onto and expand market share.

The outlook for organic agriculture in Turkey seems very positive, particularly in the export market. Eighty percent of current production is export-oriented. However, a number of challenges exist, both in domestic and export markets. Turkey should make the necessary arrangements and regulations to increase its market share in export markets. Therefore, we suggest that Turkey should:

- Improve domestic market potential and marketing facilities, which are currently inadequate. This should be funded by a partnership of government and private producer organizations as is currently done in some EU countries. This should also include programs to solve some of the existing technical problems.
- Organize and develop different institutional structures for organic agriculture vs. conventional agriculture.

- Provide information about organic products to consumers. This will increase the demand for organic products and give foreign and domestic consumers confidence in Turkish organic products.

- Establish a coordinating institution among firms who export organic products to make institutional improvements among export firms (i.e., data collection, price reporting, etc.).

- Establish technical and advisory services for organic farmers. Small-scale farmers especially need to be informed through agricultural organizations. This can be done by training existing staff on organic production and marketing procedures as well as adding additional staff.

- Encourage producer organizations of farmers engaged in organic farming. The government should provide a network for education, extension, and advisory services. Experiences from other countries can be used as a guide [e.g., organizations such as the Northeast Organic Farming Association (NOFA) in the U.S. have institutionalized the certification and educational process for organic products].

- Constitute a national program to produce and market to member states in the EU since the EU is the main export market.

- Carefully follow regulations in the EU and the world concerning import of organic products from thirdworld countries. Turkey does not need to reinvent regulations, but adopt those already developed in the major export market.

\section{Literature cited}

Achilles, D.A. 1999. Organic global agriculture information network report. U.S. Embassy, Bonn, Germany. 24 Mar. 2005. <http://www.fas.usda.gov/gainfiles/199912/25546541.pdf>.

Aikaterini, M. 2001. What motivates consumers to buy organic food in the U.K.? Results for a qualitative study, marketing trends for organic food in the 21 st century. Proc. 72nd European Assn. of Agr. Econ. Seminar. Organic Food Mktg. Trends. Mediterranean Agron. Inst. of Chaina, 7-10 June 2001. Chaina, Greece.

Akgungor, S., B. Miran, C. Abay, E. Olhan, and N. Kizıldag. 1999. The estimation of potential consumer demand for friendly environment agricultural products in Istanbul, Ankara and Izmir Provinces, 1999. Agr. Econ. Res. Inst., Ankara, Turkey.

Barrett, H.R., A.W. Browne, P.J.C.Harris, and K. Cadoret. 2002. Organic certification and the U.K. market: Organic imports from developing countries. Food Policy 27:301-318

Brumfield, R.G. 1996. Sustainable horticulture:An overview. Hort Technology 6(4):352-354.

Brumfield, R.G. 2000. An examination of the economics of sustainable and conventional practices. HortTechnology 10(4):687-691.

Brumfield, R.G., A. Rimal, and S. Reiners. 2000. A comparative cost analysis of conventional, integrated crop management, and organic methods. HortTechnology 10(4):165-173.

Buzby, J., R. Ready, and J. Skees. 1995. Contingent valuation in food policy analysis: A case study of a pesticide residue risk reduction. J. Agr. Appl. Econ. 27:81-85.

Byrne, P.J., U.C. Toensmeyer, C.L. German, and H.R. Muller. 1991. Analysis of consumer attitudes toward organic produce and purchase likelihood. J. Food Distribution Res. 22:49-62.

Council of the European Union. 1991. Organic production of agricultural products. European Union Law EC No. 2092/91 of 24 June 1991. 27 Feb. 2005. <http://europa.eu.int/smartapi/cgi/ sga_doc? smartapi!celexapi!prod!CELEX numdoc\&lg=EN\&numdoc=31991R209 $2 \&$ model $=$ guichett $>$.

Council of the European Union. 1999. Rural development from the European Agricultural Guidance and Guarantee Fund. European Union Law EC No. 1257/1999 of 17 May 1999. 24 Mar. 2005. <http:// www.esf.ie/financialcontrol/1999/ CR12571999.pdf>

Commission of the European Communities. 2002. Sixth community environment action programme. European Union Law EC No. 1600/2002 of 22 July 2002. 12 Mar. 2005. <http://www.europa.eu.int/eur-lex/en/ $\mathrm{com} /$ pdf/2001/en_501PC0031.pdf >.

Directorate-General for Agriculture. 2004. Agriculture in the European Union, statistical and economic information 2003. European Commission, Brussels, Belgium. 12 Mar. 2005. <http://europa. eu.int/comm/agriculture/agrista/2003/ table_en/index.htm>.

Dunlap, R. and C. Beus. 1992. Understanding public concern about pesticides: An empirical examination. J. Consumer Affairs 26(2):418-438. 
Export Promotion Center of Turkey. 2003. Organic agricultural products. Sector reports. Ankara, Turkey. 12 Mar. 2005. <http://www.igeme.org.tr/eng/sector/ organic.pdf $>$.

Feenstra, G., C. Ingels, and D. Campbell (with contributions from D. Chaney, M.R. George, E. Bradford, the staff and advisory committees of the Univ. Calif. Sustainable Agr. Res. and Educ. Program). 1996. What is sustainable agriculture? 12 Mar. 2005. <http://www.penpages.psu.edu/ penpages_reference/12101/121011083. HTML>.

Food Institute. 2004. A primer on the U.S. Department of Agriculture, National Organic Program. 12 Mar. 2005. <http:// www.foodinstitute.com/catalog/sampleorganic.pdf>.

Foster, C. and N. Lampkin. 2000. Organic and in-conversion land area, holdings, livestock and crop production in Europe. Commission of the European Communities, Agr. and Fisheries Programme, Project CT96-1794.24 Mar. 2005.<http://www. organic.aber._ac.uk/statistics/euroarea. htm>.

Greene, R.C. 2001. U.S. organic farming emerges in 1990s economy research service. U.S. Dept. Agr., Econ. Res. Serv., Agr. Econ. Info. Bul. AIB-770. 12 Mar. 2005. <http://www.ers.usda.gov/publications/ aib770/aib770.pdf>.

Haccius, M. and I. Lunzer. 2000. Organic agriculture in Germany. Res. Inst. Org. Agr., Berlin. 12 Mar. 2005. <http://www. organic-europe.net/country_reports/germany/default.asp $>$.

Hanson, J.C., D.M. Johnson, S.E. Peters, and R.R. Janke. 1990. The profitability of sustainable agriculture on a representative grain farm in the mid-Atlantic region, 1981-89. Northeastern J. Agr. Resource Econ. 19(2):90-98.

Jussame, R. and D. Judson. 1992. Public perceptions about food safety in the United States and Japan. Rural Sociology 57:235-249.

Kevan, P.G., V.G. Thomas, and S. Belaussoff. 1997. AgrECOLTure defining the ecology in agriculture. J. Sustainable Agr. 9(2/3):109-129.

Kortbech-Olesen, R. 2000. Export opportunities of organic food from developing countries. 9-10 May. Proc. Intl.Trade Ctr., London. 12 Mar. 2005. <http://www. ifoam.org/orgagri/worldorganics_2000_ conference.html>.
Kortbech-Olesen, R. 2003. Overview on world trade in organic food products, the U.S. market and recent trends. BioFach Congr. 2003. Proc. 14 Feb. 2003. Intl. Trade Ctr., Nuremberg, Germany. 25 Mar. 2005. <http://www.intracen.org/mds/ sectors/organic/biofach.htm>.

Lichtenberg, E. 1992. Alternative approaches to pesticide regulation. Northeastern J. Agr. Resource Econ. 19(2):83-92.

Lohr, L. 2001. Factors affecting international demand and trade in organic food products, changing structure of global food consumption and trade. U.S. Dept. Agr. Econ. Res. Ser. WRS-01-1/. 24 Mar. 2005. <http://www.ers.usda.gov/publications/wrs011/wrs01lj.pdf>.

Ozkan, B., O. Ozcatalbas, S. Yilmaz, I. Yilmaz and, G. Akpinar. 2000. Determination of consumer attitudes to organic agricultural products in Antalya province (in Turkish). Proc. 4th Turkish Agr. Econ. Congr., Turkey, 6-8 Sept. 2000.

Research Institute of Organic Agriculture. 2004. Organic-Europe. Organic farming in Europe. Provisional statistics 2002. 24 Mar. 2005. <http://www.organic-europe. net/europe_eu/statistics.asp $>$.

Rigby, D., P. Woodhouse, T. Young, and M. Burton. 2001. Constructing a farm level indicator of sustainable agricultural practice. Ecol. Econ. 39:463-478.

Rundgren, G. 2003. 364 Certification bodies in 57 countries. The organic certification directory: The organic standard. Hoje, Sweden. 24 Mar. 2005. <http:// www.organicstandard.com/The\%20Org anic\%20Certification\%20Directory\%2020sample.pdf $>$.

Sayin, C. 2002. Policy pursued and organic agriculture developments in the world, the EU and Turkey (in Turkish). Exchange Foundation Publ. No. 76-2002, Izmir, Turkey.

Sayin, C. and M.N. Mencet. 2003. The general overview of organic market structure, foreign trade and regulation in Turkey and the EU. The market for organic products in the Mediterranean region. Mediterranean Agron. Inst. of Chaina, Cahiers Options Mediterraneennes 61:31-37.
Sayin, C., B. Ozkan, and O. Ozcatalbas. 2003. Organic horticultural production and marketing in Turkey. Tanta Univ. J. Agr. Res. 28(3/11):999-1007.

Schayes, S.R. 2001. Turkey. Organic products. Organic food report 2001. Global Agr. Info. Network. U.S. Embassy Rpt.: Ankara, Turkey. 12 Mar. 2005. <http://www.fas. usda.gov/gainfiles/200106/110681068. pdf>.

Tozan, M. and A. Ertem. 1998. The history of ecologic agriculture. In: U. Aksoy and A. Altındisli (eds.). Ecologic agriculture. Ecol. Agr. Org., Izmir, Turkey.

U.S. Department of Agriculture. 2002. 2002 Census of agriculture. USDA, Natl. Agr. Stat. Serv. 12 Mar. 2005. <http:// www.nass.usda.gov/census/cenus02/>.

U.S. Department of Commerce. 2003. Total midyear population for the world: 1950-2050. U.S. Census Bureau, Intl. Data Base. 24 Mar. 2005. <http://www.census. gov/ipc/_www/worldpop.html>.

U.S. General Accounting Office. 1991. Pesticides: EPA could do more to minimize groundwater contamination GAO/ RCED-91-75. U.S. Govt. Printing Office, Washington, D.C.

U.S. National Research Council. 1986. Pesticide resistance: Strategies and tactics for management. Natl. Acad. Press, Washington, D.C. 111-129. 12 Mar. 2005. <http://print.nap.edu/ books $/ 0309036275 / \mathrm{html} / 112 . \mathrm{html}>$.

U.S. Office of Technology Assessment. 1995. Biologically based technologies for pest control. Washington, D.C.

van Ravenswaay, E. and J. Hoehn. 1991. The impact health risk information on food demand: A case study of alar and apples. In: J. Caswel (ed.). Economics of food safety. Elsevier, New York.

Willer, H. and T. Richter. 2004. The world of organic agriculture, statistics and emerging trends 2004. In: H. Willer and M. Yussefi (eds.). 24 Mar. 2005. <http://www. soel.de/ oekolandbau/weltweit.html>. 